肉油は最も小なり。又沃素價は解鯨脂肉油最も大にして長笕鯨脂 肉油之に次ぎ座頭鯨脂肉油は最す小なり。但乙前述の如く脂肉油 の特數は座地によりても異ることあるを以て，3 種の鯨脂肉油の 瞼化價，沃素價が一般に上記の闒係にあるものとは斷定し難し。

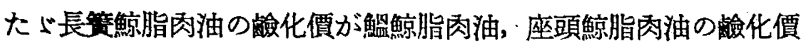
よりも概して大なることは先づ一般に通ずる事實と見て差支なか るべし。

鰓鯨脂肉油の不鹼化物含量平均值は長筼鯨脂肉油，座頭鯨脂肉 油に比し稍大なるす艋鯨脂肉油の不䠯化物含量最大は $2.70 \%$ に

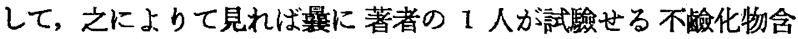

量 $10 \%$ 以上の油は恐らく抹香綡油を混淆せるものと思はる。

總括

當實驗室に 於て 煎取法に依りて探取せる 魦鯨脂肉油 45 種, 長筼鯨脂肉油 25 種, 座頭鯨脂肉油 19 種の特數を測定し比較せ り。

終りに著者は本惯驗に使用せる综脂肉を寄嘅せられたる日本水 座株式會社，殊飞多數回に互り諒脂肉を送附せられたる同社絬川 事業場, 戶畑管業所並びに鯨脂肉の䢪附に關し種々翰旋の勞を取 られたる同㖣大野英之助氏に對し深厚なる謝意を表す。

（東京工業試驗所第 2 部油脂研究窒）（昭和 12 年 9 月 20 日受理）

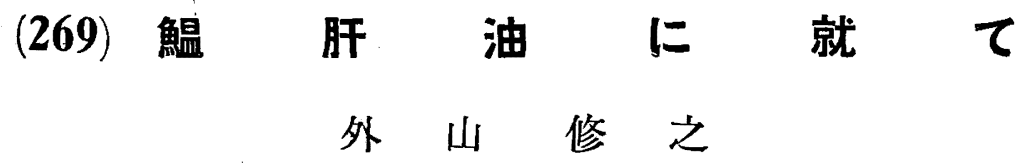

鰮油探製の原料としては觛の魚體全部を使用するを以て，普通

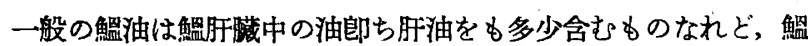
肝炡のみを原料とせる䰻肝油は未だ工業的に探製せられざるすの の如し。鰓油が懢肝臟中の油を含有する以上は多少ジィタミンA

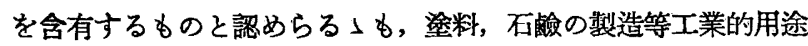
に對しては鰓油中のジィタミンA は必要ならざるべく, 又鰛油を 硬化油となして食用に供する場合にも鰮油中のヴィタミンA は既 に硬化油製造工程中に變化を受け効力を失ぶりて，結局解油中 のヴィタミン は現今全然利用せられざるすのなり。本邦に於け る鱝の產高は頗る多きを以て，若し適當なる方法に依りて鰛の肝 豚を取出乙肝油を探製せば，之をヴィタミンA の資源として利用 乙得へし。又斯くの如く触の肝兴(及其他の藏器)を取去りて爾餘 の部分より鳁油を採製せば油も摧粕も共に色相，具氣等に於て恐 らく現在品よりす良質となるならむ。但し技術上並びに探算上よ りみて現在鯭肝油の探製が實施せらるぺきや否や疑問なり。

著者は 1 昨年より昨年に瓦り朝鮮座鯭の肝膆を入手し之より肝 油を探取し其一般性狀を測定し, 又比色法に依りてヴィタミンA の濃度を測定したるを以て，此處に實驗結果を報告せむ。触朋油 のヴタミンA 濃度に關しては川上行藏氏(理研童報, 昭和 7 , 11, 968）の發表あるも, 艋肝油の特數に關しては末だ研究發表 を見ざりしものよ如し。

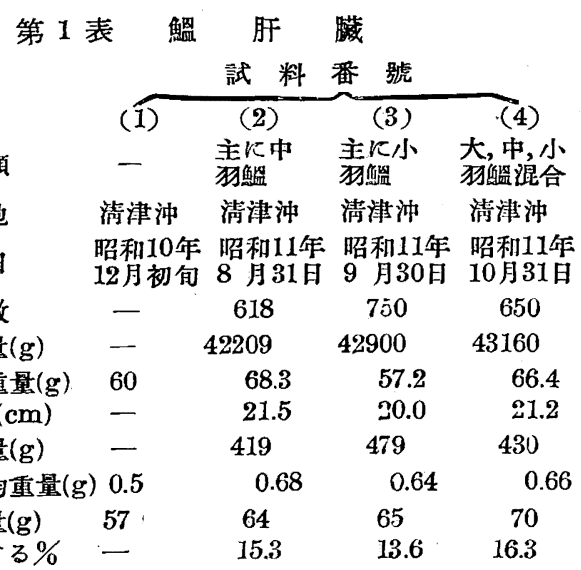

本實驗に使用せる鰮朋臟は朝蘚油脂株式會社大木松太郎氏の御 好意によりて入手せり。同氏の通信に基き肝臟に關する 2〜3の 參考事項を摘錄すれば第 1 表の如し。

第 1 表によれば探取せる艋肝臟 1 個の平均重量は $0.5 \sim 0.68 \mathrm{~g}$ なるも，實際摘出せる肝臟は肝臟全體に非らずして大體に於て肝 臟全體の $1 / 2 \sim 2 / 3$ を摘出し得たるに過ぎずと云ふっ。從て朋臟を 完全に摘出せば其總重量も第 1 表記載のものより遥かに多量に して, 肝臟 1 個の平㚬重量も亦第 1 表記載のものより遥かに大 となる筈なり。完全に摘出せる肝臟の重量は大體 $\mathrm{lg}$ 內外にして $1.5 \mathrm{~g}$ に達するものもありと云ふ。上記朋臟は清津に於て探取後, 之にアルコール（肝臟に對し約 $1 / 4$ 量）を加へガラス摆に入れ密 栓して著者の許に送附せられたり。肝油の探取には試料番號 (1) はガラス悬の內容物をエーテル約 $2 l に て$ に抽出し, エーテル抽出 液を水洗し次に脫水してェーテルを蒸溜除去し，殘留せる油分を 石油エーテルにて捕集し微量存在せる不溶解物を除き透明なる 石油エーテル溶液より石油エーテルを蒸溜除去せり。試料番號 (2)〜(4) はガラス㙾の內容物を約 3－5l の石油エーテルにて抽 出し抽出液を $50 \%$ アルコールにて洗涿し次に膯水して石油エテルを蒸溜除去せり。肝䑏探取より探油までに 10 日乃至約 2 ケ 月經過せり。肝油の收量第 1 表に記載せり。但し第 1 表肝油の 抽出に際しては抽出完全とは認め難く，又抽出液を洗涩せる際多 少乳狀態を形成し油分の損失を來たしたるを以て第 1 表記載の 收量は䆩際の含油量より稍低かるへし。斯くして得たる肝油は何
第 2 表 魦肝油の特嫩

\begin{tabular}{|c|c|c|c|c|}
\hline & & 試 料 & 番 號 & \\
\hline & (1) & (2) & (3) & (4) \\
\hline 比 重 $\left(d_{4}^{20}\right)$ & 0.9335 & 0.9347 & 0.9229 & 0.9272 \\
\hline 風折 $\left(n_{\mathrm{D}}^{20}\right)$ & 1.4829 & 1,4838 & 1.4815 & 1.4817 \\
\hline 酸 望 & 9.35 & 7.45 & 14.8 & 6.67 \\
\hline 畧俭化價 & 186.2 & 181.2 & 177.0 & 178.1 \\
\hline 沃素價(ウイイス法) & 185.3 & 186.1 & 192.9 & 194.8 \\
\hline 不献化物(\%) & 3.44 & 5.35 & 5.15 & 5.28 \\
\hline $\begin{array}{l}\text { 不檢化物中のコ } \\
レ \text { レテール(\%) }\end{array}$ & - & 49.17 & 45.88 & 57.20 \\
\hline $\begin{array}{l}\text { ×ーテル不溶性 } \\
\text { 脂肪酸臭化物 }(\%)\end{array}$ & 60.82 & 66.41 & 68.60 & 66.16 \\
\hline
\end{tabular}


れも㬐橙黄色にして多少フォスファチドを夾雜せるもの」如し。朋 油の特數を測定したる結果次の如し(第 2 表)。

不畧化物は常溫にて結晶狀固體と液體とより成れり。コレステ ロールはヂギトニン法に依りて定量せり。不羷化物をアルコール より再結晶したるに容易にコレステロールの結晶を得たり。

第 2 表によれば触肝油の沃素價は大體に於て解油に似たるも， 幾分後者よりも䯩し。各肝油は濃硫酸によりて紫色を呈したる も，呈色褐彩を帶び觧麗ならず。又ク口、フォルム溶液に於ける 三祭化アンチモンに依る呈色子溶液䟴厚なるときは極めて速かに

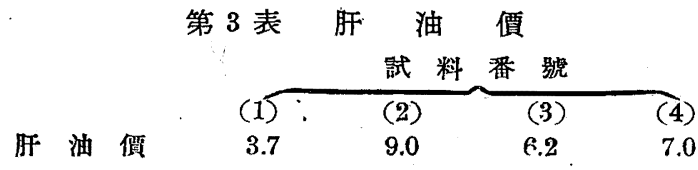

褐色となり青色明膫ならず。比色計により肝油價(C. L. O. value) を測定したるに第 3 表の結果を得たり。

川上氏 (前出) の試驗せられし鮎肝油は肝油價頗る高く 100 K 達したるも，著者の試驗せる上記 4 種の試料は肝油價甚だ低し。 此の如く同一種類の魚の肝油にありても其肝油價が著しく異る例 は他の魚類肝油の場合にも屡了遭遇する所にして, 鲖肝油の肝油 價平均值が大體どの程度のものなるかを知るには更に多數の試料 に就て試驗せざるべからず。

\section{總括}

朝鮮產鱲の肝臟より肝油を採取し其一般性狀並びに肝油價を測 定せり。

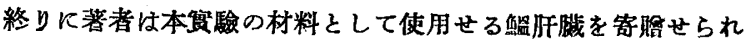
乙朝魹油脂株式會社大木松太郎氏の御好意を深謝す。

（東京工業試驗所第 2 部油脂研究室）（昭和 12 年 9 月 6 日受理）

\title{
(270) インダワンダラメ油及びカラスミ油の減壓蒸溜に就て
}

\author{
辻 本 满 丸・小 柳 牛 二
}

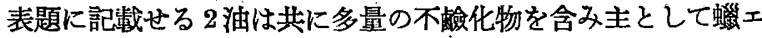
ステルより成る。イングワンダラメ油は產額少くヌカラスミ油は 學術的興味の油類に屬する 此等を蒸溜するとき如何なる溜出物 を得るやを知らんと欲して本文の實驗を行へり。

イングワンダラメ油は學名 Ruvettus tydemani Weber 々稱す る魚の躱軀より得らる」油なり。イングワンダラメなる名は沖繩 縣の方言にして東京地方にてはバラムッと稱すと云ふ。躱長 7 尺 に達する大魚なり。此油に就き最初實驗せるは木村包介氏にして 同氏は更に增淵吉長氏と共にアルコール成分に就き研究せり（本 誌, 昭和元，29，620; 東工試，昭和 3，23,[3], 43)。其結果に 依ればイングワンダラメ油は不䌞化物 $45.15 \%$ を含み檤鯨油に酷 似せり。魚類の躭油にして此の如き性質を有するものは從來記錄 を見ざりし所なり。脂肪酸の 主成分は $\mathrm{C}_{18}$ 酸なり。不验化物は 主としてセチルアルコール及びオレイルアルコールより成る。

本村氏の研究より 6 年後に至り W. M. Cox, Jr. 及び E. E. Reid 兩氏 (J.Amer. Chem. Soc., 1932, 54, 220) は米國蓙 $R u$ vettus pretiosus (タマカマス) の油に就き報告せり。此魚は米國 にて Castor oil fish と稱せらる。蓋し其油がヒマシ油の如く下 痢を起す作用ある故なりと云ふ。Ruvettus pretiosus の油はイン グワンダラメ油に酷似するもの১如し。Cox 氏等に依れば此油 は主としてオレイン酸及びヒドロキシオレイン酸 (恐らくリシ) レイン酸の異性體) のセチル及びオレイルェステルより成る。不 鹼化物中よりスクアレンの痕跡を發見せりっグリセロールは痕跡 に過ぎずと云ら。

附記 Ruvettus pretiosus の油中に假令痕跡なりをる スクアレ

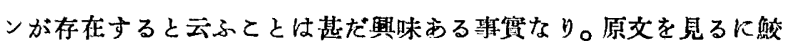
肝油の如き他油混淆の虞は無かるべし。此記事は油脂化學者化依り

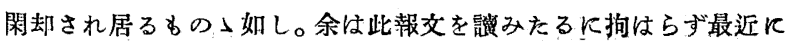
至る沦，スクアレンに關する㸝述を忘れ居たり(辻本)。
カラスミ油は食用として珍重せらる」カラスミより抽出せる油 にして元來カラスミボラの根巢中に含有せらる小油なり。著者等 の 1 人（辻本, 本誌, 昭和 $8,36,1616$ ) は始めて此油に就き實

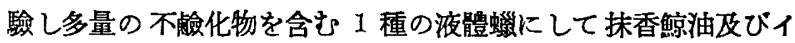
ングワンダラメ油に類似することを報告せり。脂肪酸に就ては精 查せざりしが主として $\mathrm{C}_{18}$ 酸より成るものと認められ 沃素價高 く著量の高度不飽和酸を含めり。不蔹化物の主成分はセチルア ルコール及びオクタデセノール（恐らくオレイルアルコール）な b。

加福均三及び畑忠太兩氏 (本誌, 昭和 $9,37,1035$ ) はカラス ミの原料なるカラスミボラの成熟畍巢より得たる脂肪物質に就き 研究せる結果, 脂肪酸よりパルミチン酸, ミリスチン酸, 一キサ デセン酸 (ゾーマリン酸)，オレイン酸等を檢出し少其他に $\mathrm{C}_{18}$ $\mathrm{H}_{30} \mathrm{O}_{2}$ 及び高度不能和酸 $\mathrm{C}_{18} \mathrm{H}_{28} \mathrm{O}_{2}, \mathrm{O}_{20} \mathrm{H}_{30} \mathrm{O}_{2}, \mathrm{C}_{22} \mathrm{H}_{32} \mathrm{O}_{2}$ 等が存在するらしきことを推知せり。棸不簽化物よりセチルアル コール, ニキサデセノール,オクタデセノール及びテトラデカノ ールを證明せり。

カラスミ油に關し最も興味ある點は此油の主成分が蠟エステル にして然かす著量の高度不飽和酸を含有することなり。

\section{1. イングワンダラメ油の減涯蒸溜}

（1）試料油の一般性狀 以下の實驗に用ひたる油は往年木村氏 の研究試料の残品と別口の第 2 四入手品と覥しきものとを合一せ るものなり。但し出所は同一にして大正 15 年沖䇫縣大東島東洋 製糖株式會社大東島製糖所より寄贈ぜられたるものなり。

黄色の液體にして特数等は次の如し。

\begin{tabular}{|c|c|c|c|}
\hline$d_{4}^{20}$ & 0.8733 & 沃 素 價(Wijs) & 79.0 \\
\hline$n_{\mathrm{D}}^{20}$ & 1.4650 & アセチル傮 & 7.44 \\
\hline 酸 睢 & 243 & 化 物 & $44.82 \%$ \\
\hline 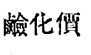 & 114.2 & $\begin{array}{l}\text { グリセロール } \\
\text { (アセチン法) }\end{array}$ & $0.54 \%$ \\
\hline
\end{tabular}

